\title{
AN ANALYSIS OF MARKETING MARGIN AND ELASTICITY OF BELL PEPPER COMMODITY PRICE TRANSMISSION (A STUDY IN CANDIKUNING VILLAGE, BATURITI DISTRICT, TABANAN REGENCY)
}

\author{
Mega Hudha*, I Gusti Ayu Agung Lies Anggreni, and Ida Ayu Listia Dewi \\ Agribusiness, Faculty of Agriculture, Udayana University, Bali, Indonesia \\ Correspondence Email: megahudha9b@gmail.com
}

Submitted 14 January 2020; Accepted 04 August 2020

\begin{abstract}
ABSTRAK
Pengembangan sektor agribisnis tidak hanya pada unit pemasaran tetapi juga upaya untuk meningkatkan produksi hasil pertanian. Salah satunya komoditi paprika. Kabupaten Tabanan merupakan kabupaten penghasil komoditi paprika terbanyak yang dijual di pasaran, di Bali. Sebagai komiditi hortikultura, paprika memiliki ciri rentan busuk dan harganya ditentukan oleh kualitas barang. Selain itu, pemasaran komoditi hortikultura secara umum cenderung melibatkan banyak lembaga yang berimbas pada harga di pasar akibat jarak antara lokasi produksi dengan lokasi pasar. Tujuan penelitian ini adalah untuk menganalisis saluran pemasaran, struktur pasar, dan efisiensi pemasaran dalam pemasaran paprika di Desa Candikuning, Kecamatan Baturiti, Kabupaten Tabanan. Adapun metode penelitian yang digunakan yakni deskriptif kualitatif pada saluran pemasaran, elastisitas transmisi harga, marjin pemasaran, distribusi marjin pemasaran, dan farmer's share. Hasil analisis menunjukkan terdapat tujuh saluran pemasaran paprika yang terdapat di Desa Candikuning. Struktur pasar yang terbentuk merupakan pasar persaingan tidak sempurna yang ditunjukkan oleh nilai elastisitas transmisi harga yakni 0,950 (Et<1). Marjin pemasaran dengan nilai tertinggi sebesar Rp 20.878,82/kg, sedangkan nilai marjin terendah sebesar Rp 6.412,96/kg. Nilai farmer's share paling tinggi sebesar 87,76\% sedangkan paling rendah yakni $66,92 \%$.
\end{abstract}

Kata kunci:_elastisitas transmisi harga, farmer's share, marjin pemasaran, paprika, saluran pemasaran

\begin{abstract}
The development of the agribusiness sector does not only focus on marketing but also on production. Tabanan is the leading producer of paprika in Bali. As a horticultural product, paprika has perishable nature, and its price is determined by the quality of the good. Besides, the marketing of horticultural commodities tends to involve many institutions which have an impact on prices in the market due to the distance between production sites and market locations. The purpose of this study were to analyze the marketing channels, market structure, and-efficiency in marketing paprika in Candikuning, Baturiti, Tabanan Regency. The research method that been used was descriptive qualitative in marketing channels, price transmission elasticity, marketing margins, distribution of marketing margin, and farmer's share. The result showed that there are seven marketing channels in Candikuning. The market structure formed as imperfect competition market which is showed by the price transmission elasticity was $0.950(\mathrm{Et}<1)$. The marketing margin with the highest value was $\mathrm{Rp}$ $20,878.82 / \mathrm{kg}$ while the lowest was Rp $6,412.96 / \mathrm{kg}$. The highest farmer share value was $87.76 \%$ while the lowest was $66.92 \%$.
\end{abstract}

Keywords: farmer's share, marketing channel, marketing margin, paprika, price transmission elasticity. 


\section{INTRODUCTION}

One of the conditions in agricultural development is the availability of a market for farmers as producers. The market not only functions as a place for sellers and buyers to marketing goods, but also functions as a driving factor for the economy in agribusiness development. Besides, the development of the agribusiness sector is not only focused on the marketing unit, but also efforts to increase the production of agricultural products for farmers. Citing a journal article by Wijaya et. al, (2012), to increase agricultural production, other commodities will also be developed in addition to prioritizing the five main food commodities, such as horticulture and plantation crops.

Bell pepper plant (Capsicum annum var. grossum L) or also known as sweet pepper is one of the horticultural plants that are classified as seasonal plants. Changes in lifestyle and consumption patterns of the population, particularly in urban areas, have stimulated an increase in demand for the bell pepper commodity, mainly for fulfilling the needs of hotels, restaurants, eating places, supermarkets, and traditional markets (Sukerena, 2016). Based on the Horticultural Statistics of Bali Province (2017), Tabanan Regency is the regency that produces the most bell pepper commodity that is provided in the market with a harvest area of 13 hectares and a production of 137 tons. The area which is the production center for the bell pepper commodity in Tabanan Regency is located in Candikuning Village. This is because the area is suitable for growing bell pepper plants with a cool climate.

The same as most horticultural crops, bell pepper also has the characteristics of a large size, is prone to rot, and the price of the commodity is determined by its quality. Generally, the better the quality of the goods sold, the higher the selling price. However, agricultural products whose quality is commonly affected by time tend to be a challenge for marketing agencies concerned in marketing their products. Every delay means a decrease in quality and loss of weight which eventually affects the selling price (Anindita, 2004). The determination of the price is not only influenced by the quality of the goods, but also the marketing costs incurred by some marketing agencies. If there are too many marketing agencies involved, the costs will be higher, which leads to the high price of bell peppers paid by consumers.

The objectives of this study were to 1 ) analyze marketing institutions and channels in the marketing of bell peppers in Candikuning Village, 2) analyze the market structure of the marketing of bell peppers commodity, and 3) analyze the efficiency of marketing in the marketing of bell peppers produced in Candikuning Village until it reaches consumers.

\section{RESEARCH METHODS}

This study was conducted in Candikuning Village, Baturiti District, Tabanan Regency, Bali. The location was selected purposively with the consideration that the area is the largest production center for the bell pepper commodity in Bali Province. This study was conducted from the end of July to mid-September 2019. The types of data used were qualitative data and quantitative data. The qualitative data in this study were a description of the general explanation of the research location, the pattern of marketing channels at related agencies, and other descriptive explanation related to the study. While the quantitative data in this study included the respondents' self-identity, volume in the transaction process both buying and selling, price transmission from farmers to retailers, costs incurred by each marketing agency in carrying out its marketing function, and the profits obtained by each marketing agency in the transaction process. Sources of data used in this study consisted of primary data and secondary data. The primary data were obtained from interviews and direct observations in the field from respondents, including bell pepper farmers, collectors, retailers, and others that are still related in the marketing flow of bell pepper commodity. Meanwhile, the secondary data were obtained 
from written sources, such as data from the Central Agency on Statistics (BPS), the Agriculture and Food Security Office, the Trade Office, and literature related to the topic of the study.

The population in this study were farmers and marketing agencies involved in the marketing of bell peppers in Candikuning Village, Baturiti District, Tabanan Regency, Bali. The sampling at the farm level was carried out using the census method with a total of 10 people. While in the marketing agency, the sampling used a snowballing technique with the starting point of sampling from farmers. By using this technique, 21 respondents were obtained consisting of collectors, wholesalers, suppliers, and retailers. The analytical methods used in this study included qualitative analysis on marketing channels, and quantitative analysis on price transmission elasticity, marketing margin, and farmer's share.

\section{Marketing Channel}

The marketing channel analysis was carried out to determine the marketing channel for the bell pepper commodity from farmers to the final consumer. This analysis can elaborate on the number of marketing agencies involved, and the flow of marketing of goods among agencies to the final consumer. The more marketing agencies involved, the longer the marketing channel that the commodity will pass.

\section{Elasticity of Price Transmission}

According to Abubakar (2016), to find out the elasticity of transmission, this formula can be used:

$$
E t=\frac{1}{b} \times \frac{P f}{P r}
$$

The Et value is the elasticity of transmission. $\mathrm{Pr}$ is the price at the retail level. $\mathrm{Pf}$ is the price at the farm level. The a value is the intercept and $b$ is the coefficient of elasticity of price transmission. According to Silitonga (2005), the results of the calculation of elasticity of transmission are described in three states. If $\mathrm{Et}=1$, it shows that the rate of price transmission at the producer level is equal to the rate of price transmission at the retail level. If $\mathrm{Et}<1$, the price transmission at the producer level is lower when compared to the price transmission at the retail level, which implies imperfect market competition. If Et $>1$, the price transmission at the producer level is higher than the price transmission at the retail level, which is an indicator of imperfect market competition.

\section{Marketing Margin and Distribution of Bell Pepper Marketing Margin}

Marketing margin analysis is used to find out the difference between the price at the consumer level and the price at the farmer level (Sudiyono, 2004). Mathematically, the calculation of marketing margin can be written as follows.

$$
M=P r-P f
$$

$\mathrm{M}$ is the marketing margin (IDR/kg). $\mathrm{Pr}$ is the price at the retail level (IDR/kg), and $\mathrm{Pf}$ is the price at the farmer level (IDR/kg). According to Darmawati (2005), the marketing margin can be considered efficient if the marketing margin obtained is low while the share received by farmers will be higher. Further, the marketing margin is considered inefficient if the marketing margin obtained is high while the share received by farmers will be lower.

Quoted in Jumiati et al. (2013), distribution of marketing costs and profits can also be used to analyze marketing efficiency by applying the following formulation.

$\mathrm{SBij}=(\mathrm{Cij} /(\mathrm{Pr}-\mathrm{Pf})) \times 100 \%$

$\mathrm{SKj}=(\mathrm{Kij} /(\mathrm{Pr}-\mathrm{Pf})) \times 100 \%$

$\mathrm{SBij}$ is a distribution of marketing costs by marketing agencies (\%). $\mathrm{Cij}$ is a marketing cost to carry out a function by marketing agencies. Pr is the price at the retail level (IDR/kg). Pf is the price at the farmer level (IDR/kg). SKj is the distribution of profits by marketing agencies (\%).

\section{Farmer's Share Analysis}

Farmer's share analysis is used to compare the price paid by consumers to the price received by farmers. Quoted in Marbun et al, (2018), farmer's share can be calculated by applying the following formula. 


$$
\mathrm{FS}=\frac{\mathrm{Pf}}{\mathrm{Pr}} \times 100 \%
$$

Fs is the value of farmer's share, Pf is the price at the farmer level, and Pr is the price at the retail level. According to Downey and Erickson (1992), farmer's share can be considered efficient if the share received by farmers (Fs) is more than $40 \%$. Conversely, if the share received by farmers (Fs) is less than $40 \%$, it can be considered that the marketing is inefficient.

\section{RESULT AND DISCUSSION}

\section{Respondent Characteristics}

There were 10 farmers who were selected as respondents in this study. In carrying out bell pepper farming, all the farmers who were the respondents were landowners. The results showed that all respondents were in the productive age category. The male respondents were seven and the female respondents were three. The results of the data also showed that the youngest and oldest age range of the respondents was 18 and 60 years, respectively. Based on the level of education, $60 \%$ of the total respondents had an education level of fewer than 10 years. The average experience of farmer respondents in carrying out bell paper cultivation was four years, while the longest experience was 10 years. Based on land tenure status, all respondent farmers were landowners who participated in land management. Most of the respondents (80\%) owned a business area of 0.05-0.09 ha.

All respondents in marketing agencies were in the productive age category, with the age range of respondents was from 34 to 62 years. The male respondents were seven and the female respondents were twelve. Based on the level of education, $61.90 \%$ of the respondents completed their education to the senior high school level. The percentage of respondents who completed education to tertiary education reached $23.81 \%$. The rest were respondents who had completed education to junior high school.

The experience of respondents in carrying out bell pepper marketing business ranged from 3-15 years. Retailers had the longest average business experience compared to other marketing agencies, which was 10 years. Meanwhile, the respondents from collectors, wholesalers, and suppliers had an average experience of five years in the bell pepper business.

\section{Marketing Channels of Bell Peppers}

Marketing agencies are individual entities or businesses that carry out marketing, distribute services and commodities from producers to final consumers and have relationships with other business entities or individuals (Sudiyono, 2004). According to Silitonga (2005), marketing channels are channels used by producers to distribute their products to consumers. Based on the results of the study, there were four marketing agencies consisting of collectors, wholesalers, retailers, and suppliers. The farmers sell bell peppers to three village collectors, two wholesalers at the Center Market of Baturiti, three suppliers, and three retailers at the Candikuning Market.

The collectors sell the bell peppers to three wholesalers, two suppliers, and two retailers in Denpasar. The wholesalers sell them to retailers in Denpasar. Meanwhile, the suppliers sell the bell peppers to retailers of large supermarkets in Denpasar, some hotels and restaurants in the South Badung and Denpasar areas. The retailers consisted of three merchants, each at the Candikuning Market and Kumbasari Market, two merchants at the Badung Market, and two supermarkets in Denpasar.

The observation results show that the total average production from the farmers in one harvest reaches $1,527 \mathrm{~kg}$ with an average total production area of 0.061 hectares $(25$ tons/ha). A percentage of $46.48 \%$ of the farmers' yields are sold to collectors, $39.09 \%$ are sold to wholesalers, $7.68 \%$ to suppliers, and $6.53 \%$ to retailers. The four agencies then formed the following seven marketing channels:

1. Farmers - Collectors - Wholesalers Retailers - Consumers

2. Farmers - Collectors - Retailers Consumers 
3. Farmers - Collectors - Suppliers Consumers

4. Farmers - Wholesalers - Retailers Consumers

5. Farmers - Suppliers - Retailers Consumers

6. Farmers - Suppliers - Consumers

7. Farmers - Retailers - Consumers

\section{Market Structure in Bell Pepper Marketing}

Market structure discusses the organization of a market so that it affects the state of competition and determination of market price. Some criteria are used to determine the market structure, including the level of concentration of buyers and sellers, the level of product differentiation, barriers to market entry, market knowledge, and market integration and diversification (Anindita, 2004). While elasticity of price transmission is the relative ratio of prices at the retail level to price transmissions at the farmer level. Based on these price transmissions, the effectiveness of market information, the form of the market, and the effectiveness of the marketing system can be estimated (Situmorang, 2011). Market structure with the elasticity of price transmission approach refers to how prices are transmitted, so this method provides an overview of the market structure based on participants' market knowledge of costs, prices, and market states.

The estimation model for price transmissions at the retail level to price transmissions at the farmer level is obtained by an equation of $\mathrm{Pf}=-2,070.44+0.779 \mathrm{Pr}+$ e. The Pr coefficient is then used to calculate the elasticity of price transmission. The results of the study conducted show that the value of elasticity of price transmission in bell pepper marketing is $0.950(\mathrm{Et}<1)$, meaning that the rate of price transmissions at the retail level is more sensitive to market responses than price transmissions at the farmer level so that the prices are transmitted imperfectly. Based on this value, it also indicates that retailers have more power in determining market prices (price makers), while farmers have more role as price recipients.

Based on the observations, although some farmers also play a role in determining prices by utilizing limited market information, retailers still more dominate market information. Thus, the role of farmers in this case does not affect market prices. This situation also implies that the market faced by marketers compete imperfectly. This is because farmers also still depend on the information provided by merchants and also the condition of the goods being traded tends to be homogeneous so that the position of farmers is less strong in determining prices.

\section{Marketing Efficiency of Bell Peppers Marketing Margin and Distribution of Bell Pepper Marketing Margin}

Table 1. Marketing Margin for Each Paprika Marketing Channel

\begin{tabular}{ccccc}
\hline $\begin{array}{c}\text { Marketing } \\
\text { Channel }\end{array}$ & $\begin{array}{c}\text { Prices at Farmer } \\
\text { Level (IDR/kg) }\end{array}$ & $\begin{array}{c}\text { Retail Prices } \\
\text { (IDR/kg) }\end{array}$ & $\begin{array}{c}\text { Marketing Margin } \\
\text { (IDR/kg) }\end{array}$ & $\begin{array}{c}\text { Share } \\
\text { Marketing } \\
\mathbf{( \% )}\end{array}$ \\
\hline I & $38.037,11$ & $54.391,06$ & $16.353,94$ & 30,07 \\
II & $38.037,11$ & $52.000,00$ & $13.962,89$ & 26,85 \\
III & $38.037,11$ & $54.655,56$ & $16.618,44$ & 30,41 \\
IV & $41.203,70$ & $54.391,06$ & $13.187,35$ & 24,25 \\
V & $42.227,84$ & $63.106,67$ & $20.878,82$ & 33,08 \\
VI & $42.227,84$ & $54.655,56$ & $12.427,71$ & 22,74 \\
VII & $46.000,00$ & $52.412,96$ & $6.412,96$ & 12,24 \\
Average & $40.824,39$ & $55.087,55$ & $14.263,16$ & 25,66 \\
\hline
\end{tabular}

Source: Processed from Primary Data, 2019 
Table 2. Marketing Margin Cost Distribution for Each Marketing Agency

\begin{tabular}{|c|c|c|c|c|c|c|}
\hline \multirow{2}{*}{$\begin{array}{c}\text { Marketing } \\
\text { Channel }\end{array}$} & \multirow{2}{*}{$\begin{array}{c}\text { Total } \\
\text { Cost } \\
\text { (IDR/kg) }\end{array}$} & \multirow{2}{*}{$\begin{array}{c}\text { Marketing } \\
\text { Activities }\end{array}$} & \multicolumn{4}{|c|}{ Marketing Agency (\%) } \\
\hline & & & Collectors & Wholesalers & Supplier & Retailer \\
\hline \multirow[t]{7}{*}{ I } & $3.905,43$ & Transportation & 3,32 & 3,29 & - & 6,66 \\
\hline & & Retribution & - & 0,16 & - & 0,48 \\
\hline & & Packaging & 0,43 & 0,41 & - & 1,36 \\
\hline & & Sorting & - & - & - & 1,30 \\
\hline & & Depreciation & 0,36 & 0,50 & - & 1,08 \\
\hline & & Labor & - & 4,55 & - & - \\
\hline & & Total & 4,10 & 8,91 & - & 10,87 \\
\hline \multirow[t]{6}{*}{ II } & $2.448,74$ & Transportation & 3,88 & - & - & 7,80 \\
\hline & & Retribution & - & - & - & 0,56 \\
\hline & & Packaging & 0,50 & - & - & 1,59 \\
\hline & & Sorting & - & - & - & 0,41 \\
\hline & & Depreciation & 0,42 & - & - & 0,34 \\
\hline & & Total & 4,80 & - & - & 12,74 \\
\hline \multirow[t]{7}{*}{ III } & $7.023,97$ & Transportation & 3,26 & - & 14,73 & - \\
\hline & & Retribution & - & - & 3,01 & - \\
\hline & & Packaging & 0,42 & - & 4,09 & - \\
\hline & & Sorting & - & - & 2,03 & - \\
\hline & & Depreciation & 0,35 & - & 0,45 & - \\
\hline & & Labor & - & - & 13,94 & - \\
\hline & & Total & 4,03 & - & 38,23 & - \\
\hline \multirow[t]{7}{*}{ IV } & $3.234,99$ & Transportation & - & 4,08 & - & 8,26 \\
\hline & & Retribution & - & 0,19 & - & 0,59 \\
\hline & & Packaging & - & 0,51 & - & 1,68 \\
\hline & & Sorting & - & - & - & 1,61 \\
\hline & & Depreciation & - & 0,62 & - & 1,34 \\
\hline & & Labor & - & 5,64 & - & - \\
\hline & & Total & - & 11,05 & - & 13,48 \\
\hline \multirow[t]{7}{*}{$\mathrm{V}$} & $8.574,84$ & Transportation & - & - & 11,72 & 4,53 \\
\hline & & Retribution & - & - & 2,39 & 0,38 \\
\hline & & Packaging & - & - & 3,25 & 1.13 \\
\hline & & Sorting & - & - & 1,61 & 1,61 \\
\hline & & Depreciation & - & - & 0,36 & 0.72 \\
\hline & & Labor & - & - & 11,09 & 2,27 \\
\hline & & Total & - & - & 30,43 & 10,64 \\
\hline \multirow[t]{7}{*}{ VI } & $6.353,52$ & Transportation & - & - & 19,69 & - \\
\hline & & Retribution & - & - & 4,02 & - \\
\hline & & Packaging & - & - & 5,46 & - \\
\hline & & Sorting & - & - & 2,71 & - \\
\hline & & Depreciation & - & - & 0,60 & - \\
\hline & & Labor & - & - & 18,63 & - \\
\hline & & Total & - & - & 51,12 & - \\
\hline
\end{tabular}




\begin{tabular}{cclcccr}
\multirow{2}{*}{ VII } & $1.566,52$ & Transportation & - & - & - & 11,93 \\
& & Retribution & - & - & - & 1,15 \\
& & Packaging & - & - & - & 4,06 \\
& & Sorting & - & - & - & 3,10 \\
& & Depreciation & - & - & - & 4,18 \\
& & Total & - & - & - & $\mathbf{2 4 , 4 3}$ \\
\hline Average & $\mathbf{4 . 7 2 9 , 7 1}$ & & $\mathbf{4 , 3 1}$ & $\mathbf{9 , 9 8}$ & $\mathbf{3 9 , 9 3}$ & $\mathbf{1 4 , 4 3}$ \\
\hline
\end{tabular}

Source: Processed from Primary Data, 2019

Based on the analysis results, the marketing channel with the highest total marketing margin is the marketing channel $\mathrm{V}$ with a marketing margin of IDR $20,878.82 / \mathrm{kg}$. While the lowest marketing margin is the marketing channel VII with a margin of IDR $6,412.96 / \mathrm{kg}$. The average marketing margin, total cost, and total profit in the bell pepper marketing channel are IDR $14,263.16 / \mathrm{kg}$; IDR $4,666.43 / \mathrm{kg}$; and IDR $9,596.74 / \mathrm{kg}$ respectively.

In channel I, the highest value of marketing margin is obtained by wholesalers, which is IDR $6,890.74 / \mathrm{kg}$. The highest value of marketing margin in channel II is obtained by collectors, which is IDR $7,990.67 / \mathrm{kg}$. Suppliers obtain the highest value of marketing margin in channel III, which is IDR $12,427.11 / \mathrm{kg}$. In channel IV, wholesalers obtain the highest value of marketing margin among other marketing agencies, which is IDR $6,890.74 / \mathrm{kg}$. While the highest value of marketing margin in channel $\mathrm{V}$ is obtained by suppliers, which is IDR $12,427.11 / \mathrm{kg}$.

In the calculation of the distribution of marketing margin, each marketing channel has a total share of costs by all marketing

agencies less than the total share of profits. However, in the marketing channel VI, the total cost share $(51.12 \%)$ is higher than the total profit share $(48.88 \%)$. Moreover, the observation results also show that the costs most budgeted by marketing agencies are related to transportation costs. The marketing agency of suppliers have the highest average share of costs, which is $39.93 \%$. This is because the average number of the commodity sold is less, which is up to $40 \mathrm{~kg}$. Concurrently, the marketing agency of retails has the highest profit distribution, which is $39.47 \%$ to anticipate unexpected risks borne by retailers in product marketing. The highest share of profits in retailers is on channel VII which is through only one intermediary. The distribution of profits in each agency can be seen in the following Table 3. The distribution of marketing margin on profit tends to be more even for each marketing agency compared to the distribution of margin on cost.

\section{Farmer's Share}

Farmer's share is a comparison of the price received by farmers with the price paid

Table 3. Marketing Margin Distribution (Profit Share) of Each Marketing Agency

\begin{tabular}{cccccc}
\hline Marketing & Total Profit & \multicolumn{5}{c}{ Marketing Agency (\%) } \\
\cline { 3 - 6 } Channel & (IDR/kg) & Collectors & Wholesalers & Supplier & Retailer \\
\hline I & $12.448,51$ & 15,26 & 33,23 & - & 27,63 \\
II & $11.514,15$ & 52,43 & - & - & 30,04 \\
III & $9.594,47$ & 21,18 & - & 36,55 & - \\
IV & $9.952,37$ & - & 41,21 & - & 34,26 \\
V & $12.303,98$ & - & - & 29,09 & 29,84 \\
VI & $6.074,19$ & - & - & 48,88 & - \\
VII & $4.846,45$ & - & - & - & 75,57 \\
Average & $9.533,45$ & 29,62 & 37,22 & 38,17 & 39,47 \\
\hline
\end{tabular}

Source: Processed from Primary Data, 2019 
Table 4. Farmer's Share in the Paprika Marketing Channel in Candikuning Village

\begin{tabular}{ccccc}
\hline No & $\begin{array}{c}\text { Marketing } \\
\text { Channel }\end{array}$ & $\begin{array}{c}\text { Prices at Farmer Level } \\
\text { (IDR/kg) }\end{array}$ & $\begin{array}{c}\text { Prices at Retail Level } \\
\text { (IDR/kg) }\end{array}$ & $\begin{array}{c}\text { Farmer's } \\
\text { Share (\%) }\end{array}$ \\
\hline 1. & I & $38.037,11$ & $54.391,06$ & 69,93 \\
2. & II & $38.037,11$ & $52.000,00$ & 73,15 \\
3. & III & $38.037,11$ & $54.655,56$ & 69,59 \\
4. & IV & $41.203,70$ & $54.391,06$ & 75,75 \\
5. & V & $42.227,84$ & $63.106,67$ & 66,92 \\
6. & VI & $42.227,84$ & $54.655,56$ & 77,26 \\
7. & VII & $46.000,00$ & $52.412,96$ & 87,76 \\
\hline
\end{tabular}

Source: Processed from Primary Data, 2019

by consumers and expressed as a percentage. Farmer's share and marketing margin have a negative relationship, meaning that the higher the marketing margin, the lower the share obtained by farmers (Marbun et al., 2018).

The analysis results of the farmer's share show that all channels are in the efficient category. Marketing channel VII is the channel with the highest share value for farmers, which is $87.76 \%$. One of the factors that cause the high and low value of farmer's share is the number of marketing agencies involved in it. However, even though marketing channel I is a channel with many related agencies in it, the lowest farmer's share is shown by marketing channel $\mathrm{V}$ of $66.92 \%$. This shows that the factors that affect the value of farmer's share do not only consider the number of marketing agencies involved.

Based on the theory expressed by Kohls and Uhl (2002), the value of the farmer's share is also affected by the level of processing, transportation costs, and the amount of product marketed. Based on this theory, marketing costs also generally have an effect on it. By reviewing Table 2., the order of the agencies with the highest to lowest marketing costs is suppliers, retailers, wholesalers, and collectors. Marketing channels that combine other marketing agencies with suppliers tend to have lower values of farmer's share due to the high accumulated marketing costs that affect the sales price for the final consumer.

\section{CONCLUSIONS}

Based on the results of the study that have been carried out, it can be concluded that there are four bell pepper marketing agencies in Candikuning Village consisting of collectors, wholesalers, retailers, and suppliers. The four agencies then form seven patterns of marketing channels so that the products reach consumers. The market structure formed, which is imperfect competition market, is showed by the elasticity of transmission value of 0.950 (Et $<$ 1) in which market information received by retailers is more sensitive in responding to market conditions compared to information received by farmers. The marketing channel for bell peppers in Candikuning Village is in the efficient criteria according to the efficiency standard of farmer's share ( $>40 \%)$. Marketing channel VII is the most efficient marketing channel with the lowest marketing margin, which is IDR $6,412.96 / \mathrm{kg}$. The distribution of marketing margin on profit tends to be more even for marketing agencies than the distribution of margin on cost.

The suggestions that can be recommended in this study are to strengthen the position of farmers regarding market information, so that it is necessary to form an association for bell peppers farmers. It is necessary to carry out further research on the market structure formed in the bell pepper commodity by using other methods, such as market share, concentration ratio, or market integration. The marketing agency of 
suppliers need to consider the aspects of marketing costs that need to be incurred in marketing bell peppers. Improvement of the cost component can be carried out by increasing the number of sales of peppers or reducing unnecessary costs.

\section{REFERENCES}

Abubakar, I., D. B. Hakim, and R. W. Asmarantaka. 2017. Struktur, perilaku dan kinerja pemasaran biji kakao di Kabupaten Parigi Moutong Provinsi Sulawesi Tengah. Forum Agribisnis 6(1): 1-20.

Anindita, R. 2004. Pemasaran Hasil Pertanian. Surabaya. Papyrus.

Darmawati. 2005. Analisis pemasaran mendong di Kabupaten Sleman. Skripsi. Universitas Sebelas Maret. Surakarta.

Downey, W. D., and S. P. Erickson. 1992. Manajemen Agribisnis. Jakarta. Erlangga.

Horticultural Statistics of Bali Province. 2017. Statistik hortikultura Provinsi Bali 2016. Denpasar: Badan Pusat Statistik Provinsi Bali.

Jumiati, E., D. H. Darwanto, S. Hartono, and Masyhuri. 2013. Analisis saluran pemasaran dan marjin pemasaran kelapa dalam di daerah perbatasan Kalimantan Timur. Jurnal AGRIFOR 12(1): 1-10.

Kohls, R. L., and J. N. Uhl. 2002. Marketing of Agricultutral Product, ninth edition. New Jersey. Prentice Hall.

Marbun, L. E., J. R. Mandei, and R. M. Kumaat. 2018. Pemasaran bawang merah di Desa Tonsewer Selatan Kecamatan Tompaso Barat. Agri SocioEkonomi Unsrat 14(1): 135-148.

Silitonga, E. H. 2005. Analisis efisiensi pemasaran sayuran dataran tinggi Kabupaten Karo Propinsi Sumatera
Utara. Jurnal Komunikasi Pertanian 17(4): 73-81.

Situmorang, B. 2011. Analisis elastisitas transmisi harga CPO (Crude Palm Oil) domestik terhadap harga TBS (Tandan Buah Segar) Sumatera Utara. Skripsi. Universitas Sumatera Utara. Medan.

Sudiyono, A. 2004. Pemasaran pertanian. Malang. UMM Press.

Sukerena, W. 2016. Nilai ekonomi dalam usahatani cabe paprika melalui sistem green house (Kasus di Desa Candikuning, Kecamatan Baturiti, Kabupaten Tabanan, Provinsi Bali). DwijenAGRO 6(2): 1-7.

Wijaya, D., S. P. Utama., and I. Cahyadinata. 2012. Analisis pendapatan dan pemasaran usahatani brokoli (Brassica oleraceae L.) di Desa Muara Perikan Kecamatan Pagaralam Selatan Kotamadya Pagaralam. AGRISEP 11(2): 173-186. 